\title{
IAMJ
}

INTERNATIONAL

AYURVEDIC

MEDICAL JOURNAL

$\underline{\text { Review Article }}$

ISSN: 2320-5091

Impact Factor: 6.719

\section{JALAUKAVACHARANA (LEECH THERAPY) ITS INDICATIONS AND COMPLICATIONS - A BRIEF REVIEW}

\section{Dighade Shubhangi ${ }^{1}$, Naringe Seema ${ }^{2}$, Sangita Jain (Gupta) ${ }^{3}$}

${ }^{1}$ Professor in Kayachikitsa, Dr. Rajendra Gode Ayurved College and Hospital, Amravati 444602, Maharashtra, India

${ }^{2}$ Professor in Swasthvrutta and Yoga, Shri Ayurved Mahavidyalaya, Nagpur440035 Maharashtra, India

${ }^{3}$ Professor in Kayachikitsa, Jupitar Ayurved Medical College, Shankarpur, Nagpur 441108, Maharashtra, India

Corresponding Author: naringeseema@gmail.com

https://doi.org/10.46607/iamj.3609012021

(Published online: January 2021)

Open Access

(C) International Ayurvedic Medical Journal, India 2021

Article Received: 28/12/2020 - Peer Reviewed: 01/01/2021 - Accepted for Publication: 02/01/2021

(D) Check for updates

\section{ABSTRACT}

Jalaukavacharana is the ancient technique used for Raktmokshana, here Jalauka means leeches and avacharana means application. Jalauka is one of the tools for Raktmokshana, among Shring, Alabu and Prachhana where Jalauka, Shring, Alabu are used for Pitta, Vata, Kahpa Doshaj Vyadhi respectively. Jalaukavacharana (leech therapy) is a non-surgical type of Raktamokshana and considered as the most unique and effective method of bloodletting. A lot of research work has been carried out in Ayurveda and Modern medicine to prove efficacy of leech therapy in various disorders. Leeches are widely used in most of the disorders ranging from skin disease to Ischemic heart disease with evidence of successful results. In the present paper effort has been made to review various scientific studies which have been conducted in Ayurveda as well as Modern medicine and study the indications of Jalaukavacharana in various disorders as per Ayurveda and Modern medicine. This paper also studies the possible complications of Jalaukavacharana.

Keywords: Jaloukavacharana, Raktmokshana, Leech therapy, Bloodletting, Hirudo therapy. 


\section{INTRODUCTION}

As per Ayurveda, Jalaukavacharan is one of the procedures of Raktmokshana. Raktmokshana is the ancient bio surgical procedure described by Sushruta, father of Indian surgery.

Ancient history suggests that lord Dhanwatari evolved in this world after Samudra manthan with Jalauka along with a pitcher filled with nectar in its hand. This shows the importance of Jalauka in Indian system of medicine. Since Jala is their life or they are habituated to the water they are called Jalauka. Raktmokshana is indicated in treatment of Rakatajroga. Individuals with aggravated imbalance between Rakta and Pitta dosha and high level of toxicity are recommended for Raktmokshana therapy. Leech Therapy has been practiced by Ayurvedic Physicians since ancient times. At the end of the 19th century use of leeches began to be less prevalent due to discontinuity in flow of knowledge. At the end of the 19th century, leech therapy again emerged, due to its role as constructive surgery. Leech therapy is widely used in plastic and reconstructive microsurgery as the protective tool against venous congestion. Raktamokshana is also used as regimental therapy for purification of vitiated body humors and should be done in autumn season. Raktmokshana is of two types one is Shastra Vistravan: use of sharp instruments for Raktmokshana, this includes: Pracchana: letting the blood pass through several incision and second is Siravedha also known as Venipuncture, this include Jalaukavacharan, Alabu and Shrunga.

Out of these procedures Jalaukavacharana is the safest as no sharp instrument is used in this therefore this can be safely used in delicate people. Jalauka is commonly habituated in Jala, so it is cold in nature and commonly used in Raktaj and Pittaj roga. There are a total twelve types of Jalauka described in Ayurvedic text. ${ }^{(1)}$ These twelve types are categorized into two main types based on their therapeutic use. Jalauka which are fit for therapeutic purposes are called Nirvish Jalauka, these were further subclassified into six types each. The Nirvish Jalauka are Pingla, Shankhamukhi, Mushika, Pundarikamukhi and Savarika.
Jalauka which are not fit for therapeutic purposes are called Savish Jalauka. These were further subclassified into six types each. The Savish Jalauka are Krishna, Karbura, Algarda, Indrayudha, Samudrika and Gochandana. Only Nirvish Jalauka are fit for the therapeutic purpose. The proper identification of Nirvish Jalauka is very essential to avoid the use of Savish Jalauka. Nirvish Jalauka are identified on the basis of their breeding grounds, their characteristic appearance and behavior, which are described in Ayurveda text.

Aim and Objectives: This study is carried out to study, Jaloukavacharana its indications in various disorders and its complications.

\section{Materials and Methods:}

All the literature related to Jaloukavacharana is collected from classical texts of Ayurveda Various research publications and books. After thorough study of research carried out in the field of Jaloukavacharana, the subject matter related to it was compiled and critically analysed in this study.

Discussion: Here we discussed the indications of Jaloukavacharana as per Ayurveda as well as modern system of medicine as follows-

\section{Indication of Jalaukavacharana in Ayurveda}

The specific indications of Jaloukavacharana which are mentioned in Ayurvedic text are Vidradhi (Abscess), Gulma (Abdominal Swelling), Arsha (Piles), Kushta (Skin Disease), Vatarakta (Gout), Koshtuk-Shirsha (Infective Arthritis), Sandhigat Roga (Osteo-Arthritis), Kantharoga (goiter), Netra Roga (Eye Disease) Granthi (Nodular Swelling), Arbuda (Cancer), Shlipada (Filaria), Vidarika (Cracks), Vishadamsha (Insect Bite), Visharpa (Erysipalas), Shiroroga (disease of scalp), Dantaveshta (pyorrhea), etc. (2) As Jalauka is indicated in diseases caused by vitiated and Rakta Pittadosha, it can be used in Raktapradoshaj vikars which are described in sutrasthana of Charak Samhita. These Rakta pradoshaj vikaras (disease caused by blood disorder) are Mukhpaka (Stomatitis), Akshiroga (redness in eyes), Puti-nasa, Asyagandhata, Gulma (Abdominal Swelling), Upkusha (Bleeding Gums), Visarpa, Raktapitta 
(Hemorrhagic Disorder), Vatashonita (Gout), Vaivarnya (Discoloration of skin), Agnisada (loss of appetite), Pipasa (excessive thirst), Gurugatrata (heaviness in body), Tikta Amla Udgara (Belching with bitter and acidic taste), Buddhi Sammoha (Confusion), Kampa (Tremors), Tandra (Drowsiness), Nidra Adhikya (Excessive Sleepiness), Tamas Atidarshana (Frequent Blackout), Kandu (Itching)and Twaka Vikara (Skin disorders). ${ }^{(3)}$

Ayurvedic research work that has been conducted by various research scholars in the field of Jalaukavacharan and its resultant observation are enlisted as follows

1. Vicharchika: study has been carried out on 34 patients of Vicharchika where Raktmokshana was done by Jalouka shows significant result without any adverse effects and recurrence. ${ }^{(4)}$

2. Khalitya: A case study of a 28 years old woman of Khalitya shows significant results after Jaloukavacharana with oral medication for regular 2 months. ${ }^{(5)}$

3. Thrombosed Piles: A patient having thrombosed external piles where Jaloukavacharana shows significant relief in symptoms like burning in anus, itching. ${ }^{(6)}$

4. Indralupta: A case study on a patient of Indralupta with local Jaloukavacharana and application of Gunja Beeja lepa shows significant results. ${ }^{(7)}$

5. Diabetic Foot Ulcer: A case study of patients with Diabetic foot ulcer was advised weekly application of leech around the ulcer along with Diabetic medicine. The ulcer healed completely within 30 days. ${ }^{(8)}$

6. Sandhivata: A pilot study where 32 patients of Sandhivata were selected and Jalauka was applied once in a week for 6 weeks, show significant decrease in symptoms like pain, stiffness and tenderness. ${ }^{(9)}$

7. Vatarakta: A pilot study was carried out on 10 patients of Vatarakta, Leech application is done once a week for 3 times, shows significant results. (10)

doi:10.46607/iamj.09012021

| IAMJ January 2021 |

www.iamj.in 
inflammatory reactions. Leech therapy is effective in conditions like osteoarthritis, abscess, cellulitis, Arthritis, systemic lupus erythematous, tendonitis, fibromyalgia.

2. Anti-metastatic action: Many researchers delineated the effective usage of leech saliva as an anti -metastatic agent and used in a wide range of malignant tumor cells such as pulmonary carcinoma, osteo-carcinoma, breast carcinoma, leukemia, etc. It also helps in relief of cancer pain.

3. Anti- hyperglycemic Action: A study which is conducted to evaluate the Anti-hyper glycemic activity of leech saliva conclude that Salivary Gland of leeches has anti- hyperglycemic effect against type-I like diabetes mellitus.

4. Anticoagulatory Effect: Leech saliva contains Hirudin which act as Thrombin inhibitory and found useful in Ischemic disease such as Ischemic heart disease, unstable angina, deep vein Thrombosis, postoperative Thrombosis, Peripheral circulation disorders, etc.

5. Leech therapy in Dentistry: Leech therapy is found very useful in Dentistry. Diseases such as Periodontal abscesses, Macroglossia, Orodental Fistula, Periodontitis, Gingivitis etc.

6. Leech therapy in Eye and ENT disorders: Leech therapy proved effective in Eye and ENT disorders like Cataract, Glaucoma, Traumatic injuries of eye, Parotitis, Otitis etc.

7. Leech therapy in Reconstructive Surgeries: The primary indication for use of leeches in the field of plastic and Reconstructive Surgeries is to prevent Venous congestion of Flaps used for soft tissue coverage of defects. Leeches have been used in constructive surgeries like ear, nose, lip and digit replantation, surgeries of maxillofacial region, breast flap (Mammoplasty) etc.

\section{Complication of Jalaukavacharan ${ }^{(19,20)}$}

Here complications of Jalauka, after studying various research work some complication which were observed during Leech Therapy are listed below

- Prolonged Bleeding time: the most common complication of leech therapy is Prolonged Bleeding time. Leech saliva contains
Acetylcholine, Histamine like Vasodilators that prolong bleeding time. In most of the cases bleeding stops after some time, but few patients may experience prolonged bleeding for more than two hours. In such cases, local application of Haridra Churna is found useful also topical Thrombin and pressure can be applied for the treatment.

- Bacterial Infection: The most serious complication is infection at the site of bite. The leech's digestive tract contains the gram-negative bacillus, bacillus, Aeromonas Hydrophilia, which breaks down the ingested blood. Infection can arise two to seven days after Leech therapy and may present as an abscess or cellulitis, with progression to sepsis possible, this gram-negative bacterium may cause infection.

- Allergic Reaction: Many patients may experience allergic reactions such as Erythema, Edema, Swelling with central black Eschar on biting point and sometimes Ulcerative Necrosis. These allergic reactions are the result of toxins found in Leech Saliva.

- Hypotension and Vasovagal attack: Some patients may experience sudden drop in blood pressure, fainting or severe complications like Vasovagal attack. This can be avoided by proper history taking. If a patient has a history of such types of attack before or followed by any other invasive treatment methods, leech therapy should not be administered.

- Fever: Fever may be present due to bacterial infection or infected wound.

- Local Pain: Many patients experienced mild dragging pain just after the leech bite which subsided after a few minutes, due to the anesthetic effect of leech saliva. A rhythmic pulling sensation is usually noticed after the start of feeding.

- Itching: Mild itching may be present at the site of bite or a few days. 


\section{DISCUSSION}

The numerous studies conducted in the field of Ayurveda and Modern medicines emphasizing the beneficial effect of Jalauka in different disease conditions. Leech therapy is found effective in various dermatological disorders like Eczema, Psoriasis, Alopecia Areata, Acne Vulgaris, Cellulitis, Herpes Zoster, Boils, Abscesses for pigment reduction in nevus Ota, Keloids, allergic skin diseases, etc. The other disease in which Leech therapy is found effective are Rheumatoid Arthritis, Vatarakta, Shlipada, Thrombosed Piles, Diabetic ulcer, Arthritis, Varicose vein, lipo-dermatosclerosis, Sciatic nerve compression, etc. The possible complications which are observed during various studies can be avoided or minimized by strictly following the exclusion criteria like Hemorrhagic Diathesis, patient on anticoagulant therapy leukemia, bone marrow suppression Cirrhosis and Cachexia, etc. The contraindications which are described in Ayurvedic text must be taken into consideration to avoid the possible complications which arise due to accidental use of SavishJalauka and can be avoided by proper identification of Jalauka. For medicinal purposes leeches breed in certified bio farms should be used. Reuse of leeches should be strictly avoided to prevent transmission of bloodborne infectious disease like HIV and Hepatitis. To avoid the secondary bacterial infection, proper purification of leech and part to be leech is must. The patients taking medicines like warfarin, Vitamin E, NSAID, Aspirin, Heparin should also be avoided. It is necessary to observe some biochemical parameters to avoid complications. These parameters are CBC, ESR, LFT, Blood Urea, S. creatinine, B.T, C.T, P.T, Blood sugar level, HIV, HCV and HbsAg etc.

\section{CONCLUSION}

After reviewing various aspects of Jalaukavacharana and medicinal leech therapy it can be concluded that leech therapy has immense potential to treat a wide range of challenging medical and surgical disease conditions. The various bioactive elements have been identified from leech saliva. There is a need to study the various aspects of these elements at its molecular level and specific therapeutic action. This will help to understand the exact mechanism of action in different disease conditions. The wider studies with more precise evidence will help to clearly understand the indication and contraindication of this therapy. The large-scale clinical studies will help to re-establish our ancient therapeutic method on scientific grounds.

\section{REFERENCES}

1. Shastri Ambika Dutta. Editor, Sushrut Samhita Sutra Sthana, Volume 1, Adhyaya 13/11 Hindi commentary $11^{\text {th }}$ edition Varanasi Chaukhamba Sanskrit Sansthan 1997, P 44.

2. Shastri Hari Sadanshiv, Editor Ashtang Hriday, shastra vidhi Adhyaya- 26/35, Sarvanga Sundari and Ayurveda Rasayana commentary, Varanasi: Chaukhamba Surabharti Prakashana; 2010 P322

3. Pandey Ganga Sahay, Editor, Pt. Kashinath Shastri Vidhyotini. Hindi commentator of Charak Samhita of Agnivesha, Volume 1, Sutra Sthana. Vidhishonitam Adhyaya, 11-16 Varanasi Chaukhamba Sanskrit Sansthan; 2006, P. 444-45

4. Bhuyan C., Dudhmal T.S., Gupta S.K., Role of Raktamokshana in the management of Vicharchika (Eczema), Indian Journal of Ancient Medicine and Yoga 2009: 2(3), 165-174.

5. Yadav C.R. Gugulothu R., A Case Study of Leech Therapy in Khalitya w.s.r. Alopecia. International journal of Pharmacognosy and Chinese medicine. 2017:5(10); 3970-74.

6. Pradnya J. Bhagat, Subhash Y. Raut, Arun M. Lakhpati, Ayu: 2012 April-June; 33(2): 261-263

7. Vasundhara R. Borakhade, International Journal of Herbal Medicine, 2005: 3(3); 24-25.

8. Nivedita Rampure, Channabasavanna B.M, Mallikarjun. Jalaukavacharan in Diabetic Foot UlcerA Case Study, Journal of Ayurveda intergrated medicine science 2017; 3: 274-278.

9. P.K Rai, A.K Singh O.P Singh, N.P Rai and A.K Dwivedi. AYU,2011; April-June, 32(2): 213-217.

10. Shashank Jha, Jonde P.D. Role of Jalaukavacharan in Vatarakta- A pilot Study, IAMJ, 2014;5(1):129-132.

11. R.D. Bapat Acharya B.S Juvekar A.S Leech Therapy for complicated Varicose Veins. Indian J Med Res, 1998;107:281-284.

12. Chatrubhuji Bhuyan, Dudhmal T.S, Gupta S.K, Jalaukavacharan Para-surgical approach to Shlipada-A 
pilot study. Indian Journal of Ancient Medicine and Yoga, 2012;5 (3):15-21.

13. Shivmangal Prasad, Bijendra Shah. Role of Leech Therapy in Management of Keloids- A Case Report, International Journal of Scientific Research, August 2018 Vol. 7 (8):12-13.

14. P.N Shilpa, T.T Shirsagar. Efficacy of Jalaukavacharan in Visarpa w.s.r to Herpes Zoster- An Observational Study. World Journal of Pharmaceutical Research, 2018;7(14):800-813.

15. Whitaker I.S, Izadi D., Butler P.E Historical Article. Hirudo Medicinalis: Ancient Origin and trends in the uses of medicinal leeches throughout history, British Journal oral Maxillofacial surgery. 2004; 42:133-137.

16. Ali K. Sig, Mustafa Guney, Erkan Ozmen. Medicinal Leech Therapy- An Overall Perspective Integrative Medicine Research 2017 December; 6(4): 337-343.

17. Eldor A., Orevi M., Rigbi M., The role of leech in medicinal therapeutic blood Rev. 1996; 10:2001-2009.

18. Das B.K. An overview on Hirudo Therapy. Ind. Res. J. Pharm. Sci. 2014; 1: 33- 45.

19. Matineh Pourrahimi, Mojtaba Abdi and Roshanak Ghods. Complication of leech therapy. Avicenna Journal of Phytomedicine. 2020; 10(3): 222-234.

20. K.S Bharanija, V. Ashok, K. Jalagandeswarar. Hydrotherapy- A Cure in Vampire's Kiss: A Review. J. Pharma. Sci. and Res. 2016;8(8): 822-827.

\section{Source of Support: Nil \\ Conflict of Interest: None Declared}

How to cite this URL: Naringe Seema et al: Jalaukavacharana (Leech Therapy) Its Indications And Complications - A Brief Review. International Ayurvedic Medical Journal \{online\} 2021 \{cited January, 2021\} Available from: HYPERLINK "http://www.iamj.in/posts/images/upload/_.pdf" http://www.iamj.in/posts/images/upload/228_233.pdf 